Historic, Archive Document

Do not assume content reflects current scientific knowledge, policies, or practices. 



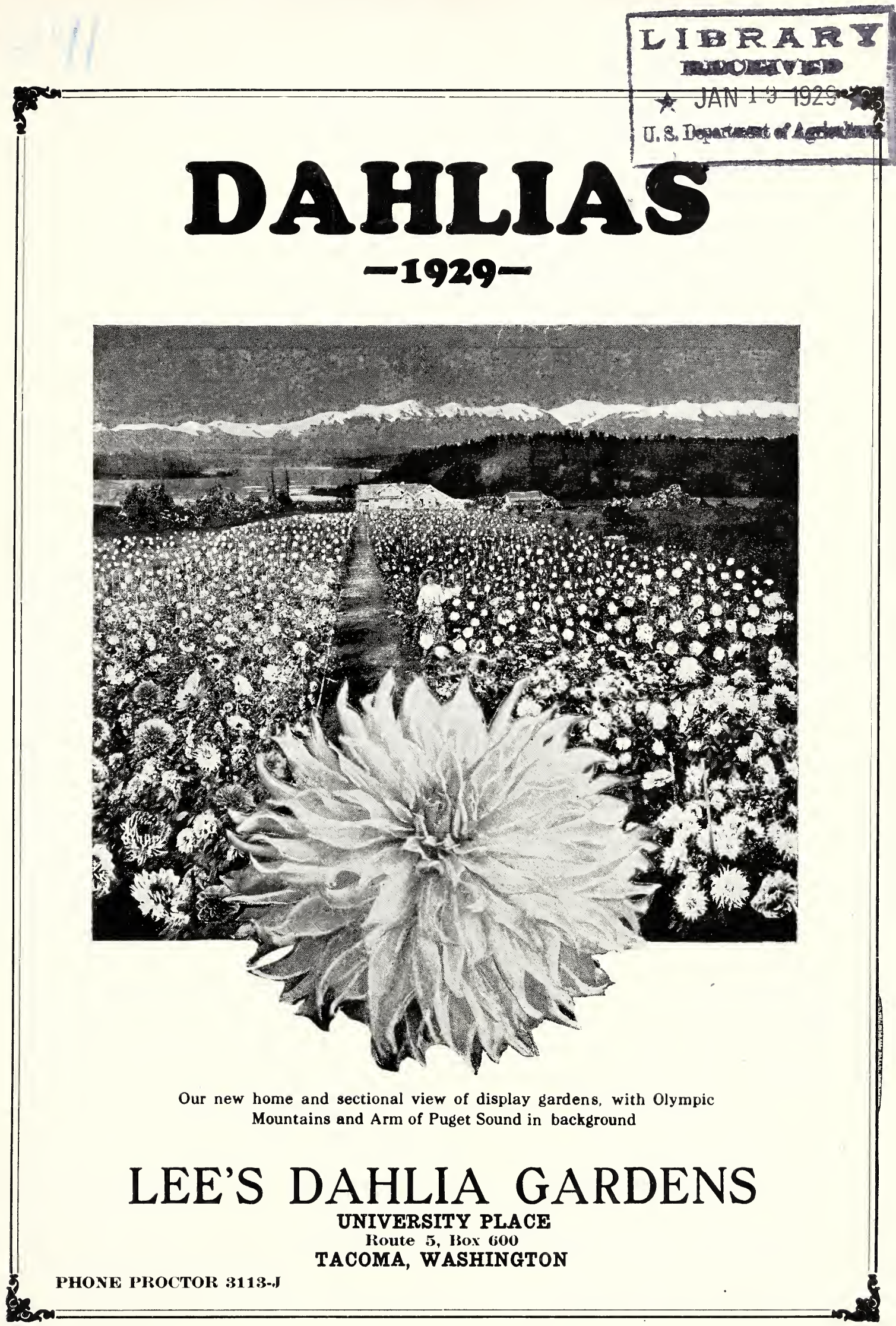




\section{GREETINGS $\odot$}

To our dahlia friends, both old and new.

We appreciate your orders and wish to thank you for the many kind letters, telling us of your success achieved with our dahlia tubers; also thank those who so kindly recomlinended us to their friends.

OUR DAHLIA GARDENS ARE THE OLDEST AND LARGEST IN THE STATE, and with our 22 years' experience in growing and specializing in dahlias, we are able to send out the best reliable tubers that can be grown.

We have moved to our new farm, where we have plenty of room and have the finest crop of dahlia tubers we have ever grown.

Send us your order and let us convince you.

\section{Best wishes to all,}

J. W. \& MRS. J. W. LEE

\section{. INFORMATION . .}

TEST GARDEN-Our own introductions and all new varieties from all parts of the world are planted in our test garden and their habits carefully noted and only those of outstanding merits are listed in our catalogue, and many are discarded each year because their habits do not come up to our standard. Our planting stock is carefully inspected both before planting and while growing, by ourselves as well as by the state inspector, and if any does not look healthy it is destroyed. Our Gardens are licensed by the state.

GUARANTEE-Our dahlias are not forced for big blooms but are grown for good tubers. Our tubers are strong and full of "pep" and we guarantee every tuber we sell to be true to name, and we will gladly replace any mistake; also guarantee each tuber to have live "eye" or sprout and if plantd right and given proper care we are sure will grow. Please notify us at once if a shipment should arrive in unsatisfactory condition.

Full Cultural Directions are sent with each order.

ORDER EARLY-Orders are reserved in the rotation received and ordering early will avoid disappointment.

SUBSTITUTIONS-We do not substitute unless instructed to do so. Please give a few second choice, especially if ordering late.

SHIPPING-We send out all orders that are paid in full, between April 15th and May 1st unless you specify a later date. Orders shipped before April 15 th at purchaser's risk.

TERMS-Cash with order. No order sent C. O. D. unless 50 per cent of purchase price accompanies order. A deposit of 25 per cent with the order will reserve the order for you, and balance must be sent before shipment. -Orders not held after May 1st unless paid in full, except by special arrangement.

POSTAGE-We pay postage on all retail orders of over $\$ 1.00$. Orders of less than $\$ 1.00$ add 10 cents postage. If you wish the tubers insured add 5 cents for insurance.

REFERENCES-National Bank of Tacoma and R. G. Dun \& Co., 'Tacoma. 


\section{Dur New 1929}

ANDORA (Dec.) - Large deep pink with mauve tint, petals very curly, stems are splendid_\$3.00

GLORIOUS SUNSET (H. Dec.)-Very large, stems good, color bright. Sunset pink and peach with tint of gold and blending to gold at base of long narrow wavy petals. A very unusual dahlia and very beautiful $\$ 5.00$

KARELA (Dec.) -Large fluffy blooms on long, strong, upright stems, color gold with tint of orange; reverse of petals salmon pink, profuse blooming

$\$ 2.50$

MARTHA JAMES (H. C.) - This has been a prize winner in the seedling class several times, also scored 86 in the Northwest trial garden, 1928. Blooms are very large, stems are long, strong and hold the blooms upright; color deep lavender with a pink tint; a splendid keeper when cut $\$ 5.00$

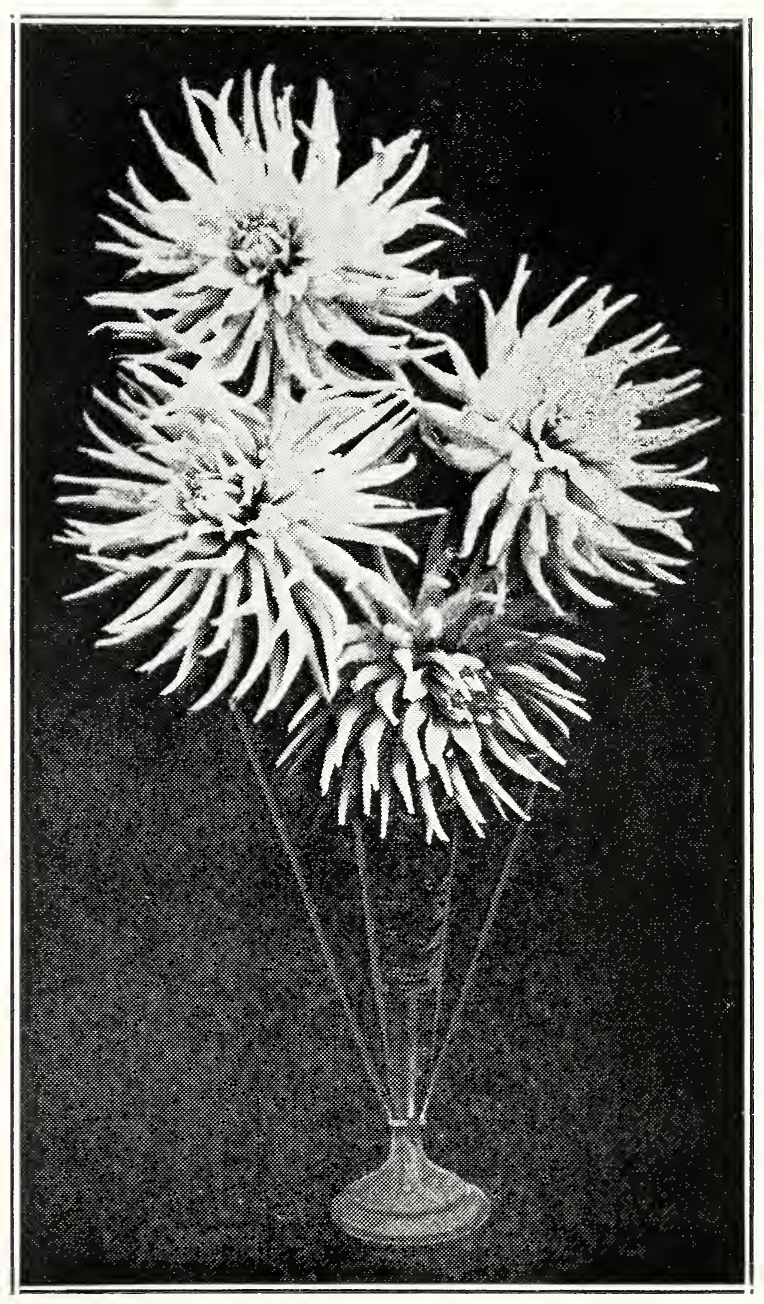

ALPHONSINE-CAC'TUS

\section{Hintroductions}

MON CHER (H. C.-A lovely cut flower variety of medium size, color pure bright pink, stems are good and plants are profuse bloomers____\$1.50

VESTELIA B. (H. C.)-Very fine wavy petals; might be classed as American cactus by some growers. Color a lovely cameo pink, blending to cream center. Stems are fairly strong; very profuse bloomer; good cut flower. This is a very cha'ming dahlia and will be a favorite $\mathbf{3 . 5 0}$

WESTERN GIANT (Dec.)-This is the largest dahila we have ever grown. We had 12-inch blooms without disbudding and grown on very ordinary garden soil, without forcing. Will be a prize finner in the big bloom sweepstake class. The stems are long, strong, and hold the big blooms up to look you in the face. Plants are medium height. Color is a very bright orange with tints of gold, reverse of petals are salmon rose. A very wonderful dahlia. Stock limited _-

\section{DAHLIAS OF REAL MERIT}

NEW AND STANDARD

\section{$\mathrm{O} \longrightarrow \mathrm{O}$}

In describing the types of Dahlias listed, the following abbreviations will be used: Cactus (Cac.); Hybrid Cactus (H. C.) ; American Cactus (A. C.) ; Decorative (Dec.); Peony (P.); Show (Sh.), and those with our name (Lee) following name of variety, are our own introductions.

THOSE MARKED WITH (*) ARE PACIFIC NORTHWEST INTRODUCTIONS.

\section{$\mathrm{O}-\mathrm{O}$}

*ADAH POMEROY (Cac.)-(Lee)-A very beautiful flower of large size, with graceful incurving petals; a delightful shade of old rose, which is overlaid with a blend of warm tan at the base of the petals. Has good habits and splendid stems. Extra good keeper when cut and has been a prize winner many times _-_-_-_-_- $75 \mathrm{c}$

*ALANNAH (H. C.) - Color a deep rose pink shading to picric yellow at base of curly reflex petals; profuse blooming and a splendid keeping cut flower on good long stems

$75 \mathrm{c}$

ALICE WHITTIER (H. C.) - One of the very finest and largest of the newer eastern prize winners. Color is a clear sulphur yellow; good substance and keeps well when cut. Stems are long and stiff, holding the massive blooms upright. A wonderful yellow $\$ 3.00$

*ALEDA MAR'TI (A. C.)-A lovely old rose, blending to yellow at base of petals. The formation is very unusual as the petals curl and twist, until the blooms are a mass of curls. Stems are long and hold blooms upright___-_50c 
* ALPhonsine (Cac.) (Lee) - A real good white cactus. The bush grows tall and carries a profusion of lovely blooms on long upright stems; perfect form, closed centers; color is white with a faint tinge of cream at center; buds when opening tinged with mauve, which turns white as flower opens _-_____

*ALTA WHEELER (Dec.)-New; very large, bright scarlet, shading to orange; yellow at the base of the petals. The blooms are held aloft on strong stems 3 feet long; a very striking flower and very much admired, and was winner of $A$. D. S. medal in the Northwest Trial Gardens, scoring in both the exhibition and commercial

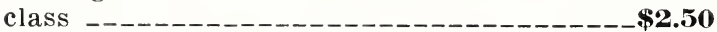

*ALVIN R. (Dec.) (Iee)-A large deep bloom with long strong stem which holds its bloom aloft and looks you in the face. A rich, velvety tyrian rose, a color very much like the well known "Daddy Butler" except that Alvin R. has a yellow halo at base of petals which makes a very striking flower. One of the best keepers when cut we have ever grown. Has won many prizes; also scored in the Northwest Trial Gardens for both exhibition and commercial class _._.

* AMERICAN GLORY (H. C.)-Very bright scarlet tipped with white. Petals are incurving, blooms are large and stems are strong and upright. Blooms profusely and is a very attractive

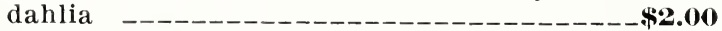

*ARCTIC (I.) - Pure white; immense size; long stems _-_-

BALLET GIRL (Cac.) - An extra large, deep flower, made up of a mass of narrow, incurved petals, color is variety of blooms of orange and white, hardly ever two alike. Very free blooming; stems are pendant _-_-

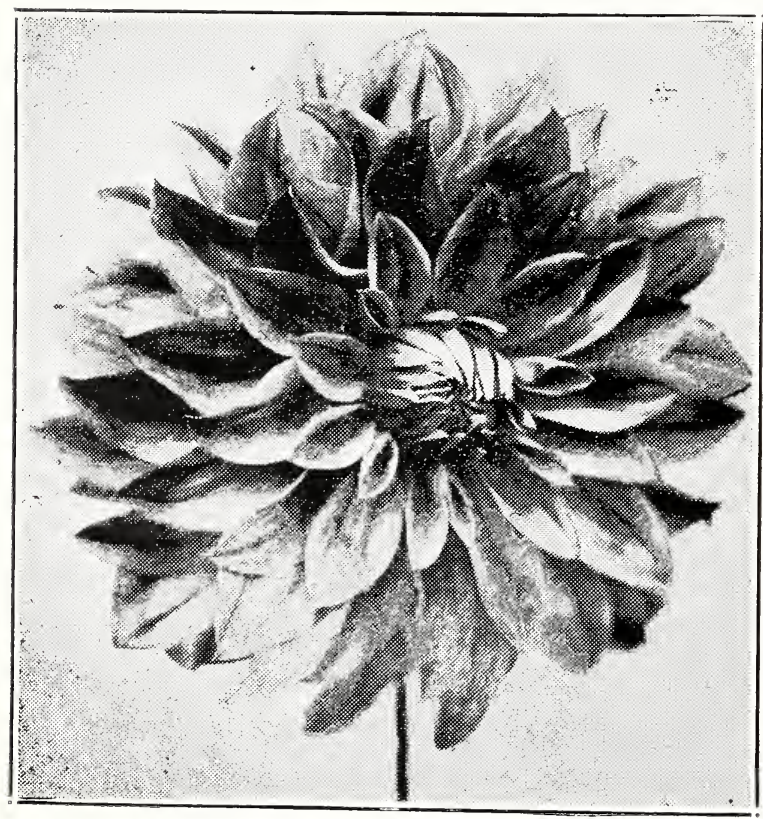

ALVIN R. (DEC.)
* BILLIE MORGA (P.) (Lee)-One of the brightest in our gardens; color scarlet red blending to yellow at the base of petals and tipped pure white. Flowers are medium size, stems are good. Very free and early bloomer and a good cut flower. Bushes medium height________50c

BLACK DIAMONI) (Sh.)-Large flowers of deep maroon, nearly black; fine for exhibition and keeps well when cut; good strong stems__-_-50c

BLACK JACK (Dec.)-Dark velvety maroon, almost black. Bushes grow tall and are profuse blooming. Flowers are very large and stems are strong and upright

$\$ 1.00$

IBOB PLUESE (H. C.)-Dark velvety crimson at base to half the length of petals, balance tIpped pure white, making a very showy flower. Blooms are large and stems are strong and upright. Keeps well when cut and plants bloom profusely. A prize winner many times_-_\$1.00

BONNIE (i. (A. C.)-Pure, soft pink. Strong grower, producing its large blooms well above the foliage in great profusion. With all lovers of pink dahlias, this is a favorite. Good cut flower on good stems _-_-_-_-_-_-_- 75c

BORDEIR KING (Cac.)-LLarge scarlet, splendid stems and very free blooming _._._-__-- $75 \mathbf{c}$

CARMENCITA (Dec.)-Clear yellow, distinctly penciled with scarlet. Very beautifully formed flower of immense size. Fine stems and a good keeper when cut; compact habit, and free bloom-

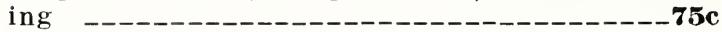

CASPER G. WARE (Dec.)-New Eastern; color is a silvery rose, blooms are large and stems are splendid; a very profuse bloomer and a very attractive dahlia _-

*CELIA F. HARIRIS (H. C.) (Lee)-A beautiful shade of bright pink, having a slight tinge of mauve. The blooms are large and full and stems are fine. Profuse blooming _-_-_- 75c

CHAMPAGNE (Dec.)-One of the very largest, color is light golden champagne with a blend of chamois. The stems are strong and hold the massive blooms absolutely upright. Plants blooms well, and is a great favorite_____- $75 \mathrm{c}$

*CHAS. F. (Dec.)-Large, rosy, watermelon pink; very beautiful blooms on good stems _-__\$1.50

CHAS. STRATTON (Dec.)-Blooms early and profusely on strong erect stems; a very large dahlia; color, old rose and pale gold_-_-_\$1.00

CIGARETTE (H. C.)-Color creamy white, heavily edged orange, but no two blooms are exactly alike. Blooms are large and of good substance. Stems are good. A dahlia very much ad-

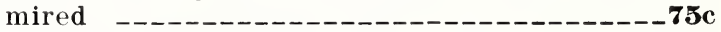

* City OF PORTland (P.)-Blooms are large, color is clear deep yellow, a graceful flower_50c

DADDY BUTLER (H. C.) -A rosy carmine or tyrian rose, the reverse of petals a lighter tint. Has splendid stems; a very profuse bloomer, and a fine cut flower which keeps extra well_-_\$1.00

DALLA (Dec.) - A large ruby red tipped silver; stems are strong and upright_-_-_-_-_-\$2.00

DICTATOR (Dec.)-Soft lavender rose, suffused with fawn; very large, fluffy blooms on long strong stems; very beautiful _- 
* DOROTHY CASTLE (Dec.) - A huge bloom on perfect stems. Color, golden cream, edge of petals have a line of apricot, something new in color and very beautiful. Blooms early and profusely

$-\$ 1.00$

DIREER'S YELLOW (Sh.) - A very large perfectly quilled, golden yellow. Good stems and good

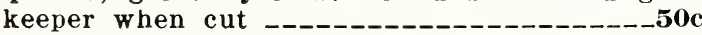

EAGLE ROCK SUNSHINE (Cac.) - A new California variety that is very beautiful. Bright golden yellow, and stems are strong and uprignt. Blooms are very large and beautifully formed. A very fine dahlia, and a big prize winner_\$2.50

EARLE WILLIAMS (Dec.) - A very brilliant crimson and white. Blooms are large and stems are strong. Plants bloom freely; a very attractive dahlia

$-75 \mathrm{c}$

EASTERN STAR (Dec.) - A large danlia on a good stem; color, a soft saffron yellow with gold shadings. Flowers of good substance and keep well when cut. Profuse blooming

$\$ 1.50$

ELITE GLORY (Dec.)-One of the newer eastern varieties that has proved to be a wonderful prize winner; coolr is a radiant bright red; one of the largest dahlias we have ever grown; stems are very strong and upright. Always attracts attention in the garden or on exhibit_____ \$4.00

ELIZABW'TH BOSTON (P.) - Very large blooms of deep crimson shading to gold at the tips; strong, free flowering habit of growth and long stiff stems. Keeps well when cut _._______-_75c

* ELIZABETH WHITE (Dec.) -A giant size, but a very graceful fluffy flower on good long stem. The color is a soft buff suffused with soft coral and salmon pink; a very pleasing flower; very profuse blooming

$-\$ 2.00$

* EMMA (H. C.) - A large fluffy, clear canary yellow, stems are excellent; a very profuse bloomer and plant looks like a big bush of Chrysantheniums

$-\$ 1.00$

ETHEL M. (H. C.)-One of the largest blooms of great depth; on strong, erect stems; color a beautiful amaranth pink blending lignter at tips. Scored 88 in A. D. S. Trial Garden --_----75c

F. A. KENT (Dec.)-Bright mallow pink on good stems

$\$ 1.00$

FAITH GARABALDI (Dec.)-Very large flowers of great depth, deep rose color shading to lighter on outer petals. An excellent decorative for exhibition; a strong free grower with good stems

$\$ 1.50$

* FAITH NEUMAN (Cac.) - A new cactus with strong stems. Color, bright golden yellow, blending to apricot at the tips of petals; blooms profusely. Won certificate of merit at Northwest Trial Garden. A splendid variety__\$1.50

* HLAMING TORCH (Dec.) - A very large flower on the very best of stems; color is a luminous flame orange. One of the most admired in our gardens and it is a profuse bloomer. Stock is always scarce of this variety on account of its popularity
F. W. FELLOWs (Cac.)-Large; bright orange; long, narrow petals; wiry stems _-_._-_.--75c

GENERAL McRAE (Dec.)-The face of the petals is apricot buff, suffused with gold, and the reverse is light coral red. The flowers are very large and perfectly formed and are held erect on extra strong stems ___________ \$1.00

GERTRUDE IRINTON (Dec.) - Large, bright scarlet; has good, strong stems, and is very attractive; keeps well when cut ________\$1.00

GLADXs BATES (A. C.)-Large blooms of soft tan color, tinted with rose; stems good and a prof use bloomer ______________- $75 \mathrm{c}$

GLORY OF NYKERK (P')-Large, purple shaded maroon; full flower on good stem _._.____50c

*GOLDEN EMBLEM (Dec.) - A clear golden yellow of large size. Very graceful formation and high centers, the petals are long and wavy, of good substance, keeping well when cut; stems are long and strong and plants bloom profusely. An attractive flower in the garden or on exhibit

$\$ 3.00$

GOLDEN WEST (H. C.) -One of the best varieties for cut flowers and is a good keeper; color bright orange-buff; blooms held erect on good stems _-_

GOLD MEDAL (Sh.)-Canary yellow and red; stems good _-_-_-_-_-_-_-_-_-_-_-_-50c

INSULINDE (Holland Dec.)-Large flower with broad, wavy petals, strong stems. Color brilliant golden orange _.

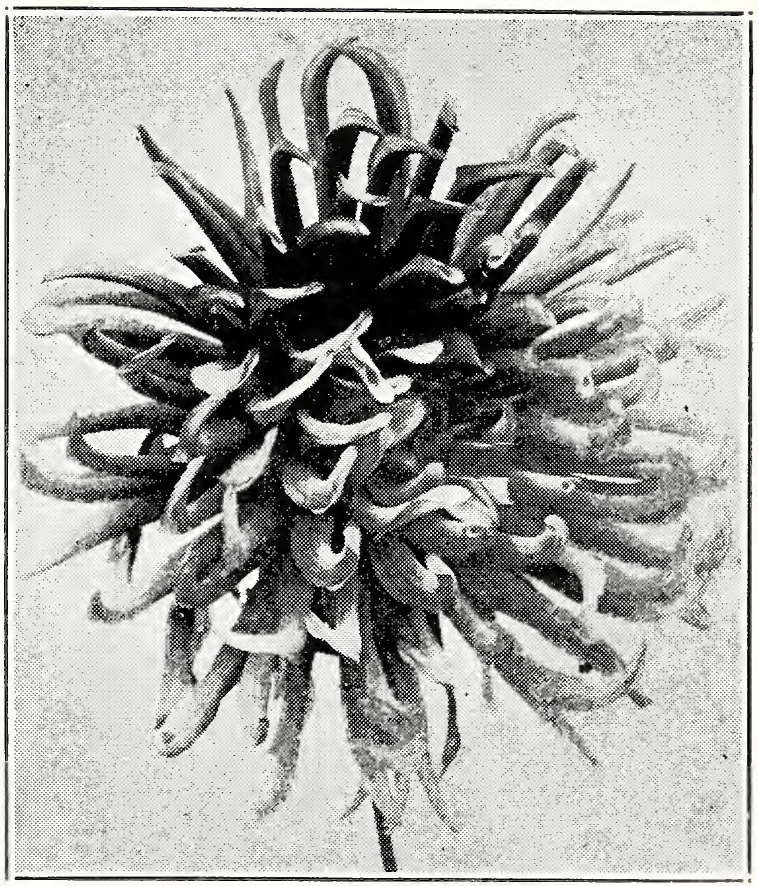

ADA POMEROY-CACTUS 
*IVORY DREAM (Curly Peony) - This dahlia is a new type in the peony class. The outside petals are $H$. C. type, while the entire center is filled with a high mass of curls. Color is ivory white with a tint of gold deep in the curls; stems are good

$\$ 3.50$

JWAY CHAZO'T (H. C.) - A very beautiful French dahlia; color autumn shades of golden bronze suffused with nasturtium red; splendid stems; profuse blooming, and good cut flower_-_-_-75c

JELSEY'S BEACON (Dec.)-Very large blowms on splendid, strong stems. Color is a Chinese scarlet with a paler reverse, giving a two-tone effect. This is a very attractive dahlia and has won many prizes

$\$ 1.00$

JERSEY's BEAU'TY (Dec.) - One of the most beautiful true pink dahlias we have ever grown; a clear pink, large, of perfect form on long, erect stems; has won many gold medals and prizes, and we heartily recommend it_-_--_-_-_-_75c

JESSIE PaLSCOTT (Dec.) - A large bright flame and orange blending lighter at tips. Stems are good and plants bloom profusely. A very beautiful autumn colored dahlia $75 \mathrm{c}$

J. M. GOODRICH (Dec.) - A medium size bloom on good, strong stems. Color salmon pink lightly tipped with gold. Not a new variety, but a splendid cut flower for keeping

$50 \mathrm{c}$

JUDGE MAREAN (Dec.)-Color is a combination of salmon pink, red, orange, yellow and gold, in a blend that is very unusual. Free blooming and has long, strong stems $-------------\mathbf{7 5 c}$

*J. W. LEE (H. C.) (Lee)-This is a magnificent dahlia of very large size. A strong grower, and profuse bloomer. The large, full, graceful blooms are held erect on good, strong stems. We find it hard to describe the color to do it justice, but as near as we can tell you it is a blending of soft scarlet on buff yellow, giving the flower the beautiful sunset shades, having a distinct halo of yellow at center. Much admired by all visitors at the gardens, and a dahlia that should be in every collection. We have good reports on it from all parts of the country. Scored in the Northwest Trial Garden, 1925, and won first prize, 1926 , in the Pacific Northwest Dahlia Grower's' Assn. Show for the best bloom of Pacific Northwest introduction entered by amateur or advanced amateur__________\$1.00

KALIS (H. C.) - A large beautiful flower; color, pure scarlet. Stems are long and strong-_-_50c

*IC. C. B. (H. C.) - A blending of old rose and golden apricot, a very beautiful flower; flowers are very large and stems are strong and up-

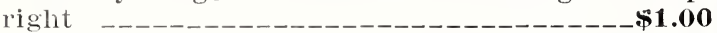

KIKU (A. C.) - Very large, beautiful bright yellow, petals incurving until blooms resemble chrysanthemums. Very profuse blooming. Stems good

$\$ 1.00$

IING OF SHOWs (Sh.) - Large deep butter yellow of a solid color throughout. Every petal is most perfectly quilled and uniquely formed; on long stems
*IEE'S WONDER (Dec.) (Lee)-A fine exhibition dahlia of very large size, growing 9 inches across when field grown. The wavy petals have great substance, being twice as thick as any variety we have ever grown. Color is a beautiful golden bronze; stems not always upright, as blooms are so heavy _-__-_-_-_-_-_-_\$2.50

LOLITA VELASCO (A. C.)-Very large, pure white, stems are splendid _-_-_-_-_-_\$1.50

*LOVE-LEE (H. C.) (Lee)-A lovely pure bright pink blending to ivory at the center. Petals are wavy and incurving. Blooms are very large and stems are long and strong. It was much admired the past season and so many would say, "How lovely"; so we named it lovely, but spelled it in our own way _-___-_-__-_\$3.00

MABEL THATCHER (Dec.)-Large flower of pale yellow; stems fair; blooms well _-_---_----75c

* MacGREgOR (H. C.)-Color is spectrum red, base of petals lemon yellow. Blooms are large and carried on long, strong, upright stems. Profuse blooming _-_-_-_-_-_-_-_-_-_-_- $75 \mathrm{c}$

MAHOGANY (C.) - One of the largest cactus we have grown; color is a rich mahogany red; a wonderful exhibition variety

*MAID MARION (H. C.) - A very large full flower of a beautiful shade of rose pink; petals curl and twist forming a graceful bloom; stems are good and it blooms profusely. A new dahlia that will be a favorite

$\$ 3.00$

MARIPOSA (H. C.) - A very large, graceful bloom with curly petals. Color is a lavender pink. Blooms very freely and has good stems__\$1.00

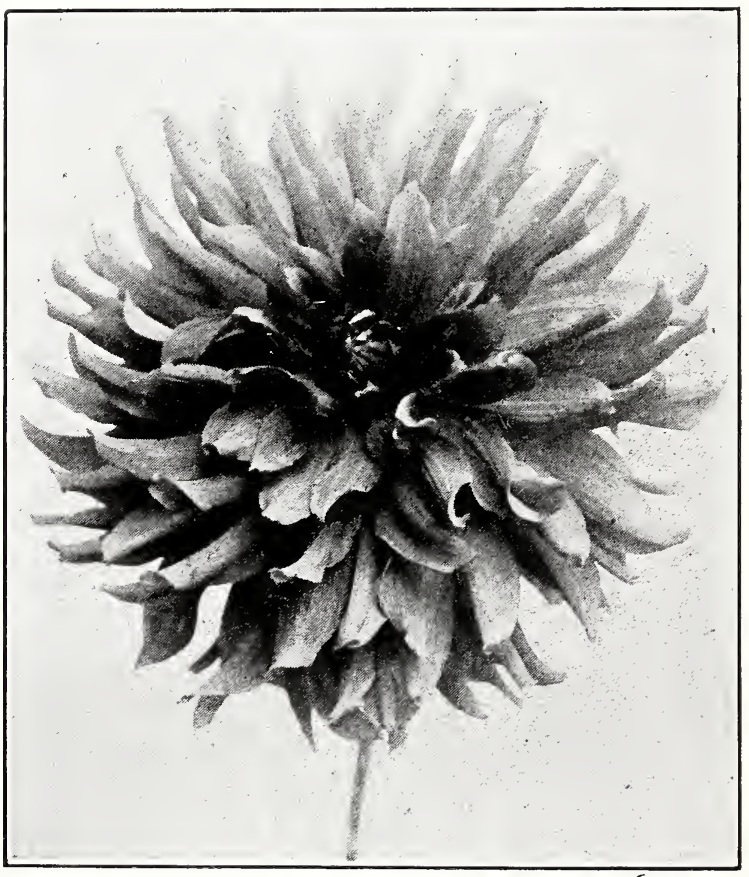

J. W. LEE (HYBRID CACTUS) 
*MARMION (Dec.) - One of the very largest dahlias. Color is pure golden yellow with bronze suffusion on reverse of petals and the deeper bronzy tone on the high, full center, and an outline of same shade around each petal enhances the beauty of the flower. Petals are long and wavy and eliminates any hint of coarseness. The long, cane-like stems hold the huge blooms erect

$\$ 4.00$

MERCEDES (A. C.) - Creamy yellow suffused with sunset pink; a large bloom on good stems. One of the earliest, and a free bloomer_______\$1.00

MERIDIAN (English C.) - Large, pale yellow bloom on good stem; profuse blooming___-_75c

MINNIE MARDEN (C.) - Watermelon pink; very profuse bloomer; stems good_______-_-_-75c

MISS CALIFORNIA (Dec.)-Very large bright rose with mauve tint, described as "Oriental fuschia." The bushes grow tall and the blossoms are very freely produced on long stiff stems. A fine cut flower as well as for exhibition_________\$2.00

MORDELLA (Dec.) - One of the outstanding eastern dahlias; color bright apricot buff. The large flowers are held well above the foliage on long strong stems__-_-__-_-_-_-__-_-_-_-_-_\$1.00

*MOROḰ (Dec.) (Lee)-Large blooms on splendid long upright stems; color is a deep gold with old rose on reverse of petals, which are wavy. This is a very beautiful dahlia_____\$2.50

MRS. ALFRED HARVEY (C.) - Large salmon pink, profuse bloomer; stems are good__-_\$1.00

MRS. C. D. ANDERSON (Sh.) - A very large purplish crimson, on good stems__________- $75 \mathrm{c}$

MRS. CARL SALBACH (Dec.)-Large blooms of lavender pink color, on very long stems; good for exhibition or cut flowers $50 \mathrm{c}$

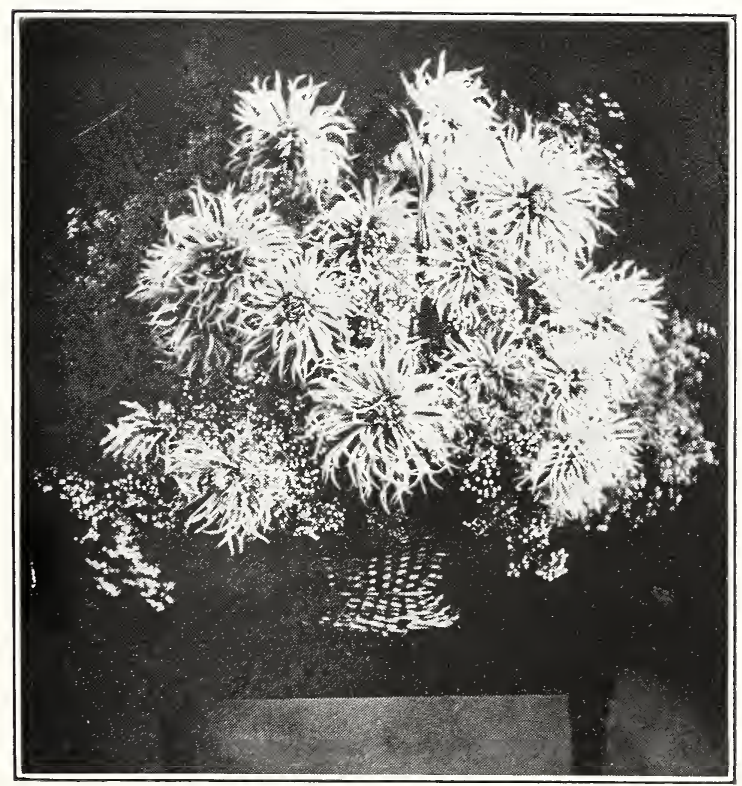

VICAR OF WASPERTON (Cac)
MRS. FRANCES E. BULLARD (Dec. P.) - A very large dahlia that will have both peony and decorative blooms, but is beautiful and has strong stems; color light silvery pink________-_\$2.00

MRS. ELEANOR MARTIN (Dec.) - One of the largest dahlias grown; color is a blending of rose and rich mulberry; an unusual color and a ver'y wonderful dahlia; stems are strong and upright. One of the favorites in the garden or exhibits

$\$ 2.00$

MRS EDNA SPENCER (A. C.) - A beautiful shade of orchid lavender and white; flowers are large and are held well above the foliage on long strong stems. Exceptionally free bloomer, and keeps extra well when cut_-_--_-_--_--_-_50c

MRS. ETHEL F. T. SMTTH (H. C.) - Creamy white shading to a lemon tint in the center. This is one of the largest dahlias. It is a profuse bloomer, and the flowers are held far above the foliage on strong stems_____-___-_-_-_-_-50c

MRS. I. DE VER WARNER (Dec.) - A charming deep mauve pink. Extra strong grower, producing its gigantic blossoms freely and rigidly erect on long, cane-like stems. A splendid variety_50c

* NATURE'S MASTERPIACE (Dec.) - A color that is hard to describe but is a blending of old rose, mulberry and metallic bronze; a rich combination. Very large blooms on extra long, strong, upright stems. Scored in the Northwest Trial Garden - - - -

* OREGON AUTUMN (P.)-Large golden buff, reverse of petals, odd cinnamon rose; stems are good _- -

*PACIFIC SUNSET (P.) - This is one of the largest peony dahlias grown and color is a pleasing blend of golden yellow and soft salmon red; an ideal autumn shade. It is also the most fragrant of any dahlia we have grown and always attracts great attention in the garden or on exhibit; stem good _-_-_-_-_-_-

PAPILLION (M. C.) - A large, graceful flower. color old rose blending with salmon bronze. A beautiful flower on good, strong stems. Blooms freely

$\$ 1.00$

PATIRCK O'MARA (Dec.)-The color is an unusually soft and pleasing shade of orange-buff. The flowers are borne on long, strong stems held rigidly erect. One of the most lasting cut flow-

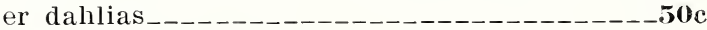

PIERRE GISARD (Dec.)-Color is currant red, a very unusual and beautiful color. Stems are splendid and blooms are very large_-_-_--_75c

POP STEWART (Dec.) - This is a wonderful dahlia of large size, fully opened blooms are a very exquisite shade of pure lilac. A fine robust grower on good stems. Scored 90 at the Trial Garden in New Jersey___-_-_-_-_-_-_\$1.00

PRIDE OF CALIFORNA (Dec.) - A large red, that has splendid stems, blooms freely and is an exceilent cut flower

$50 \mathrm{c}$

PRIMULA RFX (Dec.) - A new California variety that is one of the very largest we have grown. A very light cream or primrose yellow, lovely form, and the gigantic blooms are held erect on strong stems. Has won many prizes and is a magnificent dahlia__________________\$3.50 
RADIO (Dec.) - A true giant size; color blood réd and tipped yellow; a flower that attracts immediate attention. Flowers have great depth as well as width, and are held erect on strong stems _-_-_-_-_-_-_-__-_-_-_-__\$1.00

REGEN' (A. C.) - Large blooms, clear mauve pink; incurving petals; stems are good and it is a free bloomer.-_-

RHEINISCHER FROSHINN (Cac.) - Not a new dahlia, but a very popular one with cur customers. Color is white at base of petals, quickly blending to bright carmine rose. Petals incurved. Stems good, and it is free blooming_-_---_-50c

ROSE FALLON (Dec.) - Large dull old gold;

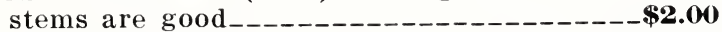

*IROBERT H. (H. C.) (Lee)-A hybrid cactus with fine petals, which are almost American type. Color is a bright American beauty blended with carmine. Blooms are large; stems are good and it is a profuse bloomer._______- \$2.00

ROSA NELL (Dec.) - Color a clear, bright rose; flowers are very large, and stems are splendid. A very attractive dahlia_-__-_-_-_-_-_50c

ROSALIA STYLES (P.)-Large bright pink tipped a lighter shade; stems are good and it blooms profusely

IROSE MARIE (Dec.) -Eastern variety, that is an unusual color, a blend of apricot bronze and old rose, yellow at the base of petals. Blooms are very large and stems are splendid. A dahlia that has attracted lots of attention in our gardens

$\$ 1.00$

SAGAMORE (Dec.) - Color a golden yellow shaded with amber at the center; large blooms on good stems. A good keeping cut flower-____-\$\$1.00

SALBACH'S WHITE (Dec.) - A new California variety, of perfect form; color, ivory white; blooms are very large and of wonderful substance. Has splendid stems and plants are profuse blooming _._-

SANHICAN'S MAGNATE (Dec.).-A splendid exhibition decorative of a pale amaranth pink, tinged with a deeper shade while reverse of petals are a deep claret color. Stems are strong and upright

SENOIITA (Dec.) - One of the largest dahlias, a rich dark red, with good stems _-____\$1.00

SHIRLEY OLIVER (Dec.) -Very large flower of light rose pink with blend of yellow at base of petals. It is held proudly erect on long stems, and is a profuse bloomer

SHUDOW'S LAVENDER (Dec.) - Very large blooms on good, strong, upright stems. Color is a beautiful lavender. Has won many prizes_\$1.00

SILVERHILL PARK (English Cac.) - It is massive in size, beautifully incurved in form and with perfect center; color is a glistening white; the plants are strong and stems are fairly good --

SISKIYOU (H. C.) — This California dahlia has carried off many prizes for the largest dahlia in the show and is surely a giant size. Blooms are held erect on very strong stems. Color is pink tinged with mauve

$\mathbf{\$ 1 . 5 0}$
SKAGERRAK (H. C.) -A beautiful sulphur yellow, very profuse blooming, and flowers are large; stems are good _._...._._._._._.

SULPHUREA (Hybrid Dec.) - A large sulphur yellow on splendid stems, one of the first to bloom and the plants are always covered with blooms until frost _._.

SUPT. AMRHYN (Sh.)-Large, bright rose pink; splendid stems and a fine cut flower-_-_-_- $75 \mathrm{c}$

SURPRISE (H. C.)-Rich orange amber, bright yellow center; medium size blooms on good stems; good cut flower _-

SUSAN G. TEVIS (Dec.)-Very large blooms on good, strong stems; color is a deep shade of lilac with a blue sheen; free blooming-_-_\$1.00

SUZANNE CAYEUX (Cac. - Beautiful, large, creamy white; free blooming; on good stems_50c

SWEE'THEAR'T'S BOUQUET (P.)-Color salmon rose, shaded with fawn; pleasing alike in both day and artificial light; flowers are large, and stems extra long; one of the very earliest to bloom and continues throughout the season_50c

SYDNEY JONES (English C.)-One of the best cactus dahlias grown; very large full flower; fine petals and stems perfect; color a soft rose pink with tint of lavender and shading to tan gold at base of petals; very free blooming_\$1.50

*SY NCOPATION (H. C.)-Large showy blooms of cherry red and yellow. Stems are splendid; free blooming; always attracts attention. Scored in the Northwest Trial Garden _-_______\$2.50

*'TACOMA (Dec.) (Lee)-Large full flowers of goodform; a beautiful yellow suffused with scarlet and gold; a seedling from Geisha and similar in color; good stem and free blooming--50c

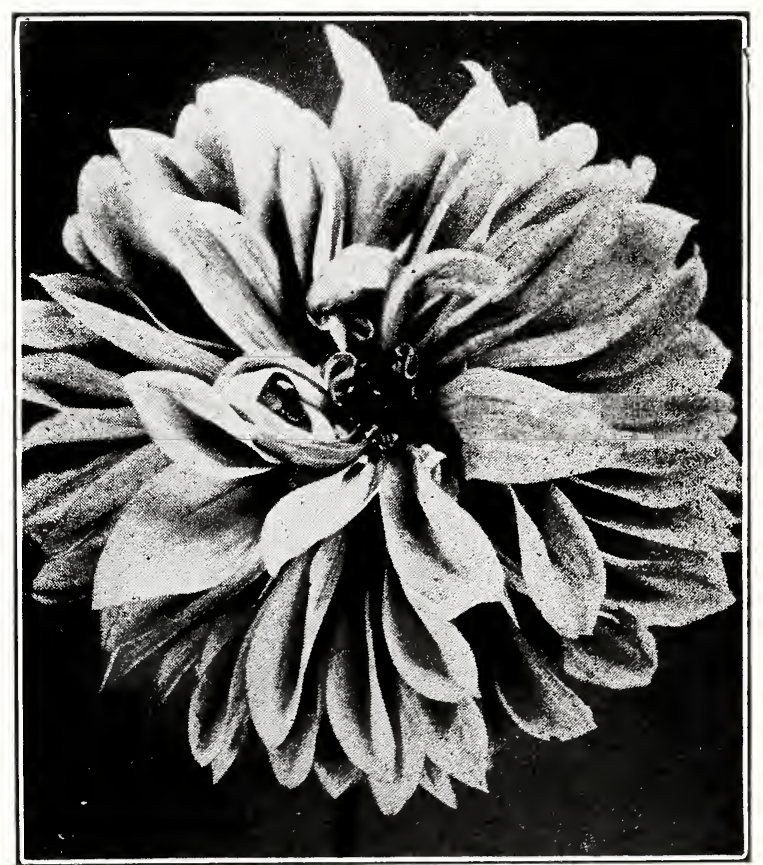

PEONY FLOWERED—Sweetheart's Bouquet) 
TALISMAN (H. C.) - A large brownish red reverse of petal gold, making a very showy flower. Stems are good; sometimes blooms peony type --

THE BANDIT (H. C.) - A very striking color; spectrum red with back of petals buff yellow; petals wave and curl, making a very attractive flower; blooms are large and stems are good and it blooms profusely _-_-_-_-_-__-_-\$2.50

THE ORIOLE (P.)-A California peony that is very striking. The color is a combination of burnt orange, red and yellow, many of the flowers shading to white at tips; large, full flowers on good stems -

THUNDERBOLT (Sh.)-Large rich cardinal red, stems good _-_

TOMMY ATKINS (Dec.) - A startling flame scarlet with a metallic lustre that glistens in the sunshine. The flowers are large and held erect on strong stems. A very beautiful dahlia; profuse bloomer _-

TRENTONION (Dec.) - A very large dahlia of a real autumn brown, a wonderful blending of gold, amber and coppery bronze with central zone a reddish bronze; perfect form, and splendid stems _.___.

TRESOR ANVERSOIS (Dec.)-A new Belgian variety that is very fine; large flowers of a most exquisite shade of lilac with light blue tints. The nearest to a real blue dahlia we have ever grown; petals are long and wavy and blooms are held aloft on splendid stems; profuse bloomer and keeps well when cut

$\$ 1.00$

UNCLE SAM (P.) - A very large bloom, color orange buff with a pink tint; stems are good and it blooms freely _-_--_-_-_-_-_-_-_-_-\$1.00

UNCLE TOM (Dec.) - A new eastern variety that attracts lots of attention in our gardens and on exhibit. A very dark velvety red that is almost black. The blooms are very large and the stems are splendid; profuse blooming _________\$2.05

VICAR OF WASPERTON (English Cac.) - Beautiful pink with cream center and tips; very large, and on good stems

* VIVIAN LANTER (H. C.)-Verỹ iarge, lavender pink. Very free blooming, and stems are long, strong and upright. A fine cut flower and good keeper $\$ 1.50$

VULCAN (English Cac.) - Very large, dark maroon with small florets at base of incurving petals, giving flower very unique appearance; good stems _-___-__-_-_-_-

WHITE COLOSSE (Dec.)-Large, full flowers, white with flesh tinge; very long, strong stems _-

* WINSTON (H. C.) -A large, golden amber with a bronze sheen; has long, strong, upright stems. A very beautiful dahlia. Scored in the Northwest Trial Garden_-_-

WIZARD OF OZ (Dec.) - A gigantic size, one of the largest grown. Color is a rare shade of glowing amber pink, with soft salmon shades. The stems are erect and stout, but need disbudding for length
WOLFGANG Von GOETHE (H. C.)-Flowers are medium size, color is a clear coral red; stems are good. One of the best for cut flowers and it is a profuse bloomer

W. W. RAWSON (Sh.)-Large flowers of pure white tinted lavender; very free blooming on good stems --_-

YANKEE KING (Dec.) - Very large bloons of coppery rose and gold; stems are long and hold the big blooms proudly erect. Scored in both Northwest and Eastern Trial Gardens. A profuse bloomer and a very wonderful dahlia_\$5.00

*ZorITA (H. Sh.) (Iee)-Large flower on good, long stems; very profuse bloomer; color apricot buff with reverse of old rose; a beautiful coloring and good show dahlia

\section{COLLARETTE DAHLIAS}

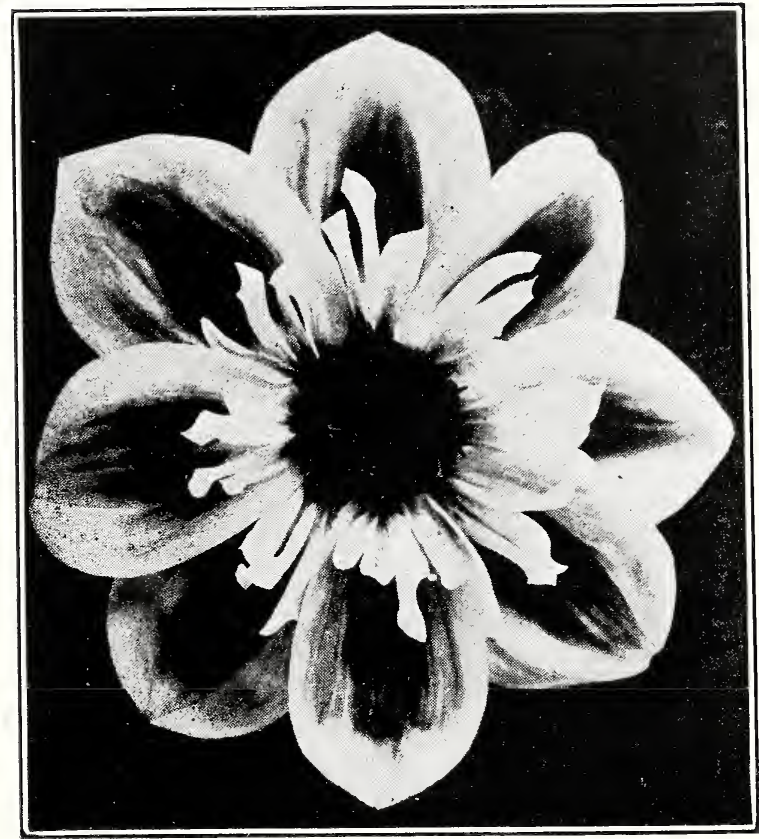

COLLARETTE DAHLIAS

GEANT DE LYON - A large flower of rich, velvety maroon, with a white collar. It is a free and constant bloomer, with fine stems _-____-_50c

KATCHEN VON SWARTZEL-A large carmine rose, petals edged with white and collar is white

* LEAH-Even visitors who were not admirers of this type had to stop and admire this gem. A large flower held erect on very stout stems. Deep crimson maroon, while the collar is white and maroon. Some flowers come variagated maroon and white _-_-_-_._-_-_-_..-_50c

* RAGGED QUEEN (Iee)-Deep pink with extra long collar of pink and white $\mathrm{k}$ 
SCARLET QUEEN-Brilliant scarlet, with golden collar; fine erect habit and very effective__-50c

SILVER MHDAL-Crimson maroon, edged cream with cream collar; very beautiful; good

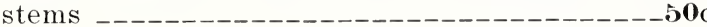

SWALLOW-Beautiful pure white collarette; long erect stems, fine for cutting _-__-__-__-_-_35c

*YELLOW BUTTERELY (Lee)-Large; very bright canary yellow with yellow collar tipped lightly with white. Very beautiful. Good stems $-50 \mathrm{c}$

\section{n-O \\ POMPON DAHLIAS}

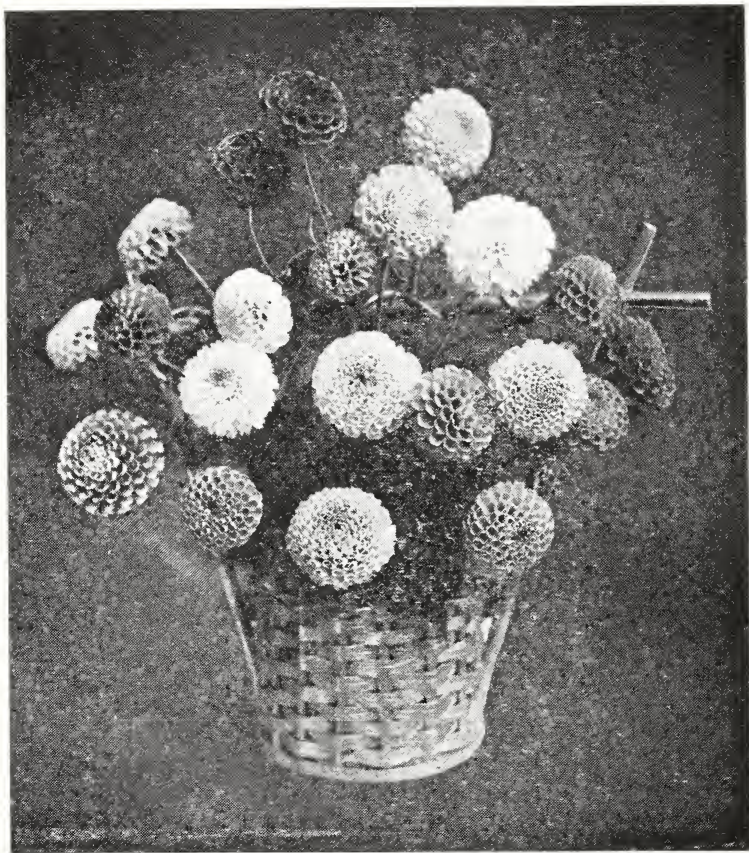

OLB CHOICE 12 VARIETIES ALL LA(BELEDI) $\$ 3.50$

Aimee-Small bronze, splendid .50

Amber Queen-Golden amber and orange --_ .35

Annie Doncaster-Pearly lavender pink, yellow base

Baby-White edged with lavender - - - - - -

Dandy-Bright orange

Darkest of All-Maroon, very dark

Dae Dee-Small lilac, very good

* Dusky Babe (Lee) -Small, rich crimson_-_

Wlizabeth-New. Golden yellow edged brownish red

Girlie-Mauve pink

Guiding Star-Pure white, notched petals_-_-

Grafin Anna von Schwerin-A very beautiful small clear pink, blending to white center
Hazel - Small bronzy brown tipped buff yellow Henrietta-Cream base, tipped crimson_-_--

Ideal-Pure canary yellow

cupfer-Deep salmon pink with tan

Little Beeswing-Small yellow, tipped cherry red

Iittle Bugler-Small rosy purple _-_-_-_-_- .35

Little David-New small orange scarlet _-_- .50

Little Fred-Very small deep rose pink _-__- .35

Little Jennie-Primrose yellow _-___-__-_ .35

Lyod Hickman-Good old rose _-_-_-_-_--- .50

Madeline-Pale yellow, edged purple______- .35

Midget-Small salmon pink _-__________- .35

Mrs. J. J. Kynn-Very small, deep, bright orange

Nellie Frazer-Blush tipped rose _-_-_--_-_

Nerissa-(True, and very scarce), soft rosy pink

Nora Reynolds-Small Indian red. San Toy-White, tipped carmine rose _-__-_ .35 Tommy Keith-Cardinal red, tipped white_- .35 Vivid-Very bright red _-_-_-_-_-_-_-_-_- .35

Verida Flora- $\Lambda$ real green pompon dahlia_- .50

\section{$\mathrm{O}-\mathrm{O}$ \\ SINGLE DAHLIAS}

WTOILE DE FOCH - A new type from France. Blooms are star shape, the petals are gold color with moired carmine reverse, and petals roll forward so it shows the reverse, a very unusual dahlia. Stems are good and it blooms profusely -

NEWPOR'T WONDER-Very large salmon rose pink, pointed petals, stems good. Has won many prizes in the East for best single_-_-_-_-_- $75 \mathrm{c}$

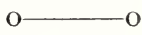

DELPHINIUMS-We have a very choice collection of the best American and English Hybrids. Seed saved only from the very best. Packet

\section{0}

35

35

5

5

5

0

5




\section{SPECIAL BARGAIN “GET ACQUAINTED' COLLECTIONS

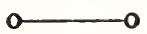

This entire collection of fine varieties for-_\$5.00 Regular value $\$ 7.50$

You save $\$ 2.50$

Alannah $\$-.75$

Carmencita .75

Cigarette .75

Dorothy Castle

Elizabeth Boston

Mabel Thatcher

Mrs. Ethel F. T. Smith

Mrs. T. De Ver Warner

Rose Marie

Vicar of Wasperton

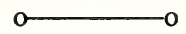

\section{CUT FLOWEIR COLLECTION \$3.00}

These are all fine varieties ror cutting. Regular value $\$ 4.25$

You save $\$ 1.25$

Golden West $\$ .50$

J. M. Goodrich

Mrs. Carl Salbach

Mrs. Edna Spencer

Pride of California

Supt. Amhryn

White Colosse

Wolfgang Von Goethe

\section{NORTHWEST TRIAL GARDEN FOR} NEW DAHLIAS

A Northwest Trial Garden, affiliated with the American Dahlia Society, has been established at the Western Washington Experiment Station, Puyallup, Wash. Mr. Harry D. Locklin, Horticulturist, has charge of the garden. Here new seedlings 2 or more years old may be tried out and they will be judged, scored and registered under the rules of the American Dahlia Society. Varieties scoring 85 or more points will receive certificate of merit

Entry fee, $\$ 2.00$. Tubers will be returned at end of season.

Entry blanks may be obtained by writing $\mathrm{Mr}$. Locklin in care of the Station.

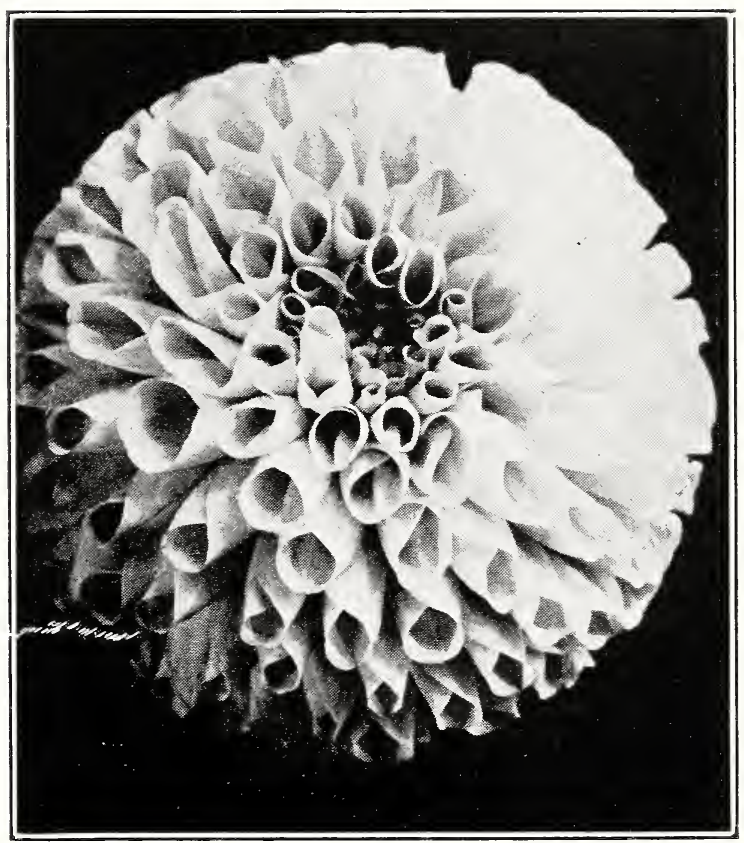

SHOW DAHLIA-W. W. RAWSON

WRITE YOUR NAME AND ADDRESS PLAINLY.

Address your letters to

\section{LEE'S DAHLIA GARDENS}

Route 5, Box 600

UNIVERSITY PLACE

Tacoma, Washington 


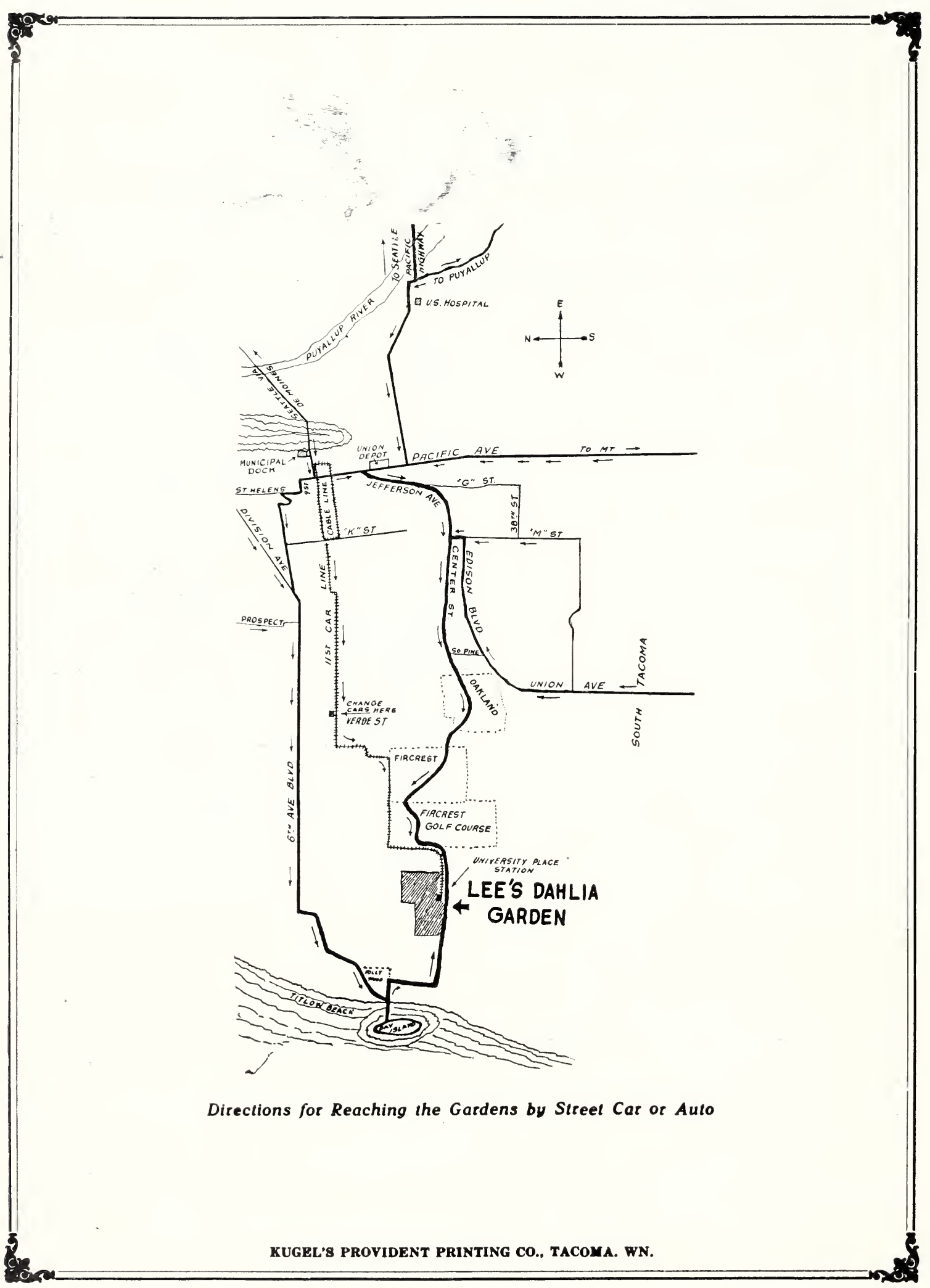

